\title{
Generation of scFv-Monoclonal Antibody Avian Influenza Diagnostic Tests
}

\author{
Tarigan S, Sumarningsih \\ Indonesian Research Center for Veterinary Sciences \\ RE. Martadinata St. No. 30 Bogor
}

(received 28-09-2018; revised 25-01-2019; accepted 28-01-2019)

\begin{abstract}
ABSTRAK
Tarigan S, Sumarningsih. 2019. Pembuatan antibodi monoklonal-scFV untuk Uji Diagnostik Avian Influenza. JITV 24(1): 2938. DOI: http://dx.doi.org/10.14334/jitv.v24i1.1871

Kebutuhan alat diagnostik cepat atau point-of-care diagnostic test untuk penyakit Avian Influenza di Indonesia sangat besar. Sampai saat ini alat diagnostik tersebut diimpor sehingga harganya mahal. Akibatnya, pengadaannya membutuhkan anggaran yang besar. Komponen utama alat diagnostik cepat adalah antibodi monoklonal yang spesifik terhadap virus influenza. Penelitian ini bertujuan memproduksi mAb yang bisa mengenali semua subtipe Avian Influenza menggunakan teknologi phage display. Influenza-A focused $\mathrm{scFv}$ library komersial di panning menggunakan rekombinan NP H1N1 dan virion H5N1 secara bergantian. Sedangkan bakteriofag yang terikat pada antigen panning dielusi dengan serum dari ayam yang memiliki antibodi terhadap virus H5N1. Phagemid dari suppressor E. coli (TG1) yang terinfeksi bakteriofag yang menampilkan anti-NP pada permukaanya diisolasi lalu ditransformasikan pada non-supressor E. coli (HB2151) untuk mengekspresikan NP-scFv. Antibodi monoklonal NP-scFv dengan berat molekul sekitar $27 \mathrm{kDa}$ dipurifikasi dari supernatan biakan menggunakan kolom kromatografi nikel. Jumlah NP-scFv murni yang diperoleh adalah sekitar $1.2 \mathrm{mg} / \mathrm{L}$ biakan. Sebagai komponen tambahan untuk penggunaanya dalam immunoassay, antibodi terhadap NP-scFv diproduksi pada kelinci. Antibodi poliklonal yang dihasilkan mengenali NP-scFv dengan spesifik dan sensitif. Antibodi monoklonal anti-NP-scFv dan poliklonal anti scFv yang dihasilkan dalam penelitian ini dapat digunakan untuk pengembangan alat diagnostik point -of-care Avian Influenza.
\end{abstract}

Kata Kunci: Avian Influenza, Nukleoprotein, Antibodi scFv, Alternating Panning, Uji POC

\begin{abstract}
Tarigan S, Sumarningsih. 2019. Generation of scFv-monoclonal antibody Avian Influenza Diagnostic Tests. JITV 24(1): 29-38. DOI: http://dx.doi.org/10.14334/jitv.v24i1.1871

The need for rapid diagnostic tools or point- of- care diagnostic tests for Avian Influenza in Indonesia is very high and the price of these imported diagnostic tools is very expensive. As a result, a large budget requires to provide the needs. The main component of a rapid diagnostic tool is the monoclonal antibody $(\mathrm{mAb})$ specifically recognized influenza viruses. The objective of this study was to produce mAb that can recognize all subtypes of Avian Influenza viruses using the phage display technology. Influenza-A focused $\mathrm{scFv}$ commercial library was panned using alternating recombinant H1N1 NP and H5N1 virions. Whereas, bacteriophages bound to the panning baits were eluted with serum from H5N1-infected chickens. Phagemid from suppressor $E$. coli (TG1) infected with bacteriophage displaying anti-NP on its surface was isolated and then transformed into a non-suppressor E. coli (HB2151) to express NP-scFv. Monoclonal NP-scFv antibody with a molecular weight of about $27 \mathrm{kDa}$ was purified from the culture supernatant using a nickel-chromatography column. The amount of pure NP-scFv obtained was around $1.2 \mathrm{mg}$ $/ \mathrm{L}$ culture. As an additional component for its use in immunoassays, antibody to NP-scFv was produced in rabbits. The generating polyclonal antibody recognized the NP-scFv specifically and sensitively. The anti-NP-scFv monoclonal antibody and the anti rabbit scFv polyclonal antibody produced in this study are envisaged appropriate for the development of diagnostic tools for point-of-care for Avian Influenza.
\end{abstract}

Key words: Avian Influenza, Nucleoprotein, scFv Antibody, Alternating Panning, POC Test

\section{INTRODUCTION}

The H5N1 avian influenza seems to be one of the most devastating zoonotic diseases ever known to date (FAO 2013). One of the main factors causing the rapid, wide spread of the disease was the delay in diagnosis and implementing actions to eradicate the disease. Diagnosis of infectious diseases that spread rapidly such as $\mathrm{AI} \mathrm{H} 5 \mathrm{~N} 1$ requires the availability of rapid or point-of -care diagnostic (POC) tools. Most of the POC diagnostic tools for Influenza both for human and poultry are based on monoclonal antibody specific against the nucleoprotein of the type A Influenza virus (Tarigan 2016). The main advantages of using monoclonal include batch-to-batch homogeneity and excellent specificity. Polyclonal antibodies are much easier, cheaper and faster to produce but the variability between different batches produced in different animals at different times is unavoidable. In addition, since polyclonal antibody comprises huge number of 
antibodies recognizing different epitopes, cross-reaction is inescapable (Liu 2014; Shalit et al. 1985).

Two approaches to produce monoclonal antibodies are currently available. The first approach was the hybridoma technology introduced by Kohler and Milstein (Kohler \& Milstein 1975). This approach involves fusion of B-cells from immunized donor animal with myeloma cell to generate immortal cells producing monoclonal antibody. Some drawbacks of this approach include the use of animals and the limited species of animal as the source of antibody that can be used. So far, myeloma cells that available for that purpose are only mouse and rat origin (Liu 2014).

The second approach for production of monoclonal antibody is the phage display technology introduced in the late $20^{\text {th }}$ century (Smith \& Petrenko 1997). Briefly, the approach began by isolation of mRNA from Blymphocites from donor animals or human, either naïve or immune to a relevant antigen. The heavy variable (VH) and light variable (VL) segments are amplified and connected with a short linker with PCR then batchcloned into a special phagemid vector, next to the pIII protein of filamentous bacteriophage. A competent $E$. coli strain is transformed with the phagemid and is rescued with a helper phage to derive a single chain variable fragment ( $\mathrm{scFv}$ )-phage library. Each phage in the library recognizes different epitope through the $\mathrm{scFv}$ that fused to the bacteriophage surface protein PIII. The diversity of a scFv library is usually in the range of millions to trillions. The next most important step is to select and purify scFv-phages that recognize the desired antigen by the protocol known as panning. Phagemids from the $E$. coli harboring $\mathrm{scFv}$ phage are isolated and transformed into competent cells of a non-suppressor strain of $E$. coli in order to express the $\mathrm{scFv}$ antibody (Clackson et al. 1991; Hoogenboom et al. 1998).

Production of $\mathrm{mAb}$ using the phage display approach offers many benefits. Once a library is made or purchase commercially, the same library can be used to generate many different mAbs. The production does not require the use of animal. Unlike maintaining hybridoma, which requires liquid nitrogen; maintaining and storage of E. coli, phagemid and bacteriophage for future $\mathrm{mAb}$ production are easy. The molecule of phage-display mAb is ease to modify; such tagging with other peptides or increase its affinity through an affinity maturation process. The phage-display mAbs penetrate tissue more easily because of its small molecular size (Liu 2014; Nissim et al. 1994; Thompson et al. 1996).

The aim of the present study was to produce $\mathrm{mAb}$ recognizing a common antigen for type-A- influenza viruses, the nucleoprotein, using the phage display technology. The mAb is envisaged suitable as the main component of POC test for influenza in animals and human.

\section{MATERIALS AND METHODS}

\section{Library and $E$. coli strain}

Ready-to-panning H1N1 library (human scFv) was obtained from Oak Bioscience, Sunnyvale, CA (USA). This H1N1-focused library, which was developed from human B-cells, had a diversity of $10^{5}$ and a titer of $10^{11}$ plaque forming unit (pfu)/ml. Helper phage $\left(\mathrm{M}_{13} \mathrm{O}_{7}\right)$ and $E$. coli TG1 (K-12 glnV44 thi-1 $\Delta$ (lacproAB) $\Delta$ (mcrB-hsdSM $) 5\left(\mathrm{r}_{\mathrm{K}}^{-} \mathrm{m}_{\mathrm{K}}{ }^{-}\right) \quad \mathrm{F}^{\prime}$ [traD36 proAB ${ }^{+}$lacI $^{\mathrm{q}}$ lacZ $\left.\left.\Delta \mathrm{M} 15\right]\right)$ and $\mathrm{HB} 2151$ E. coli (K12 (lac-pro), ara, nalr, thi/F'[proAB, lacIq, lacZ M15] from Creative Biolab, Shirley, NY, USA. Recombinant nucleoprotein H1N1 Influenza virus (NP), anti-M13 monoclonal antibody (Sino Biological, China), and antiH5N1 serum was obtained from chicken that had been vaccinated and infected with life $\mathrm{H} 5 \mathrm{~N} 1$ virus in our previous study (Tarigan et al. 2015). The H5N1 subtype influenza virus was an Indonesian isolate, previously isolated from chicken (Tarigan et al. 2015).

\section{Delipidation of H5N1 virion}

The purpose of removing lipid from the H5N1 virion is to increase the binding capacity of viral proteins to polystyrene immunotube or plate. Delipidation was carried out according to a previous method (Cham \& Knowles 1976). Briefly, virus suspension in PBS $\left(10^{7} \mathrm{EID}_{50} / \mathrm{ml}\right)$ was mixed with 2 volumes of butanol and $d i$-iso prophyl ether mixture (40\%: 60\%). After shaking for $60 \mathrm{~min}$, the mixture was centrifuged (1000 x $G, 10 \mathrm{~min})$ and the organic phase was discarded. An equal amount of ethyl ether was added to the aqueous phase, shaking and centrifuged as previously. This ethyl-ether treatment was repeated in order to remove residual butanol. Finally, the delipidated virion suspension was aliquoted and freezedried.

\section{Panning}

Two immune tubes were coated at $4^{\circ} \mathrm{C}$ overnight with NP $(2 \mu \mathrm{g}$ in $1 \mathrm{ml})$ and delipid $\mathrm{H} 5 \mathrm{~N} 1$ virus $\left(10^{7}\right.$ in 1 $\mathrm{ml}$ carbonate buffer, $\mathrm{pH}$ 9.6), respectively. After washing 4 times with PBST (PBS plus $0.05 \%$ Tween20 ) and blocking with $1 \%$ bovine serum albumin (BSA) for $2 \mathrm{hr}, 1 \mathrm{ml} \mathrm{H} 1 \mathrm{~N} 1$ library containing $10^{11} \mathrm{pfu}$ in $1 \mathrm{ml}$ PBS was added and incubated for $2 \mathrm{hr}$ at $37^{\circ} \mathrm{C}$. After removing unbound phages by washing 10 times with sterile PBST and twice with PBS, $1 \mathrm{ml}$ chicken-antiH5N1 serum (diluted 1: 50 in 2YT broth) was added, incubated at $37^{\circ} \mathrm{C}$ for $30 \mathrm{~min}$ with $250 \mathrm{rpm}$ shaking to release phages bound to NP or H5N1. 
The eluted phage suspension was filtered $(0.2 \mu \mathrm{m}$ pore) and added to $9 \mathrm{ml} \log$-phase TG1-E. coli. After incubation stationarily at $37^{\circ} \mathrm{C}$ for $30 \mathrm{~min}, 20 \mathrm{ml} 2 \mathrm{YT}$ broth containing $2 \%$ glucose and $150 \mu \mathrm{g} / \mathrm{ml}$ carbencillin were added and incubated at $37^{\circ} \mathrm{C}, 250 \mathrm{rpm}$ shaking until mid-log phase $\left(\mathrm{A}_{600}=0.5\right)$. Helper phage $2.4 \mathrm{x}$ $10^{11}$ pfu were added and incubated stationarily at $37^{\circ} \mathrm{C}$ for $30 \mathrm{~min}$. After the incubation, the bacterial cells were pelleted and suspended in 2YT medium containing 100 $\mu \mathrm{g}$ carbencilin $/ \mathrm{ml}$ and kanamycin $50 \mu \mathrm{g} / \mathrm{ml}$. After incubation overnight at $37^{\circ} \mathrm{C}, 250 \mathrm{rpm}$ shaking, the bacterial cells were pelleted; the supernatant was removed and filtered with $0.45-\mu \mathrm{m}$ filter. A one-fifths volume of PEG-NaCl (20\% polyethylene glycol 8000 in $2.5 \mathrm{M} \mathrm{NaCl}$ ) was added to the supernatant, left at $4^{\circ} \mathrm{C}$ for at least $30 \mathrm{~min}$, and then centrifuged (7000 x $G, 30$ min). The pelleted phages were suspended in PBS containing $20 \%$ glycerol, aliquoted and stored at $-70^{\circ} \mathrm{C}$ until used.

The second round of panning was carried out similarly, except that both collection of phages, i.e phages with NP and those with $\mathrm{H} 5 \mathrm{~N} 1$ baits in the first panning, were each panned with NP and H5N1 baits. Four different collections of phages were produced: NP-NP, NP-H5N1, H5N1-H5N1 and H5N1-NP, identified with the first and second baits. In the third round of panning, the four collections of phages were panned against NP, and phages bound to NP were eluted with $0.1 \mathrm{M}$ glycine- $\mathrm{HCl} \mathrm{pH} 2$. A mid-log phase TG1 E. coli culture was infected with each of the eluted phages and plated on 2YT agar containing $100 \mu \mathrm{g} / \mathrm{ml}$ carbencillin and $2 \%$ glucose. Individual colony, $10-15$ colonies per collection of phages, was picked up randomly and grown on $2 \mathrm{ml} 2 \mathrm{YT}$ medium. At mid-log phase, the scFv phages were rescued with helper phage. The reactivity of scFv-phages was determined with a phage ELISA.

\section{Phage ELISA}

A 96-well plate (maxisorp, Nunc Inc.) was coated with $50 \mathrm{ng} /$ well $\mathrm{NP}$ at $4^{\circ} \mathrm{C}$ overnight. After 2-hr blocking with $2 \% \mathrm{BSA}$, the third panned phages were added, approximately $10^{11} \mathrm{pfu} /$ well, and incubated at $37^{\circ} \mathrm{C}, 250 \mathrm{rpm}$ for $2 \mathrm{hr}$. After 5 times washings with PBST, rabbit anti $\mathrm{M}_{13} \mathrm{O}_{7}$ phage, diluted $1: 2000$ in PBS containing $5 \%$ normal chicken serum was added, and incubated at $37^{\circ} \mathrm{C}, 250 \mathrm{rpm}$ for $2 \mathrm{hr}$. After 5 times washings with PBST, substrate and ABTS were added and optical density $\left(\mathrm{A}_{420}\right)$ were measured.

Phagemids were isolated from TG1 E. coli containing the strongest reactivity of phages using a commercial kit (QIAprep mini prep kit, Qiagen). The isolated phagemid were kept at $-20^{\circ} \mathrm{C}$ until use.

\section{Transformation and clone selection}

The competent cells were prepared according to a previous methods (CHUNG et al. 1989). Briefly, HB2151 E. coli, at early log-phase in LB broth $\left(\mathrm{A}_{600}=\right.$ 0.35 ) was pelleted (1000 x G, $10 \mathrm{~min})$. The pellet was suspended in transformation solution (10\% polyethylene glycol 8000, 5\% DMSO and $50 \mathrm{mM}$ $\mathrm{MgCl}_{2}$ ), one-tenth of its original volume). The cell suspension was aliquoted in $100 \mu \mathrm{l}$ tube and kept in $80^{\circ} \mathrm{C}$ until used.

For transformation, $1 \mathrm{ng}$ or $0.1 \mathrm{ng}$ phagemid in $1 \mu \mathrm{l}$ volume was added to the $100 \mu \mathrm{l}$ competent cells and incubated at $4^{\circ} \mathrm{C}$ for $30 \mathrm{~min}$. After adding $0.9 \mathrm{ml} \mathrm{LB}$ broth, the suspension was incubated at $37^{\circ} \mathrm{C}, 250 \mathrm{rpm}$ for $1 \mathrm{hr}$, then plated in LB agar containing $100 \mu \mathrm{g} / \mathrm{ml}$ carbencillin. After incubation overnight at $37^{\circ} \mathrm{C}$, individual colony, selected randomly, was touched lightly with a toothpick and suspended in $0.5 \mathrm{ml} 2 \mathrm{YT}$ broth containing $100 \mu \mathrm{g} / \mathrm{ml}$ carbencillin and $2 \%$ glucose. For scFv expression, $10 \mu \mathrm{l}$ of the bacterial suspension is added to fresh 2 YT broth containing 100 $\mu \mathrm{g} / \mathrm{ml}$ carbencillin and $0.5 \%$ glucose $\left(2 \mathrm{YT}_{\text {-carb-glu }}\right)$ and incubated at $37^{\circ} \mathrm{C}, 250 \mathrm{rpm}$. At mid-log phase growth $\left(\mathrm{A}_{600}=0.5\right), 0.1 \mathrm{~m} M$ IPTG was added and the cultures were incubated at $30^{\circ} \mathrm{C}, 250 \mathrm{rpm}$. Following overnight incubation, the bacterial cells were pelleted, and $100 \mu \mathrm{L}$ supernatant was added to a 96-well micro-titration plate that had been coated previously with $20 \mathrm{ng}$ NP/ well. After $2 \mathrm{hr}$ incubation, the plate was washed 5 times with PBST, $100 \mu$ l anti-human 2Fab (Abcam) diluted 1: 100 was added and incubated $2 \mathrm{hr}$. After washing 5 times, substrate and ABTS was added, and OD was measured after 15 and 30 minutes. Clones producing the highest OD were selected for further production of NP-specific scFv.

\section{Expression and purification of scFv}

Selected transformed E. coli were grown in 2YTcarb-glu to mid-log phase, and incubated overnight at $30^{\circ} \mathrm{C}$ after induction with $0.1 \mathrm{~m} M$ IPTG. The bacterial cells were pelleted $\left(8000 \times \mathrm{G}, 4^{\circ} \mathrm{C}, 20 \mathrm{~min}\right)$ and the supernatant was removed. Purification of $\mathrm{scFv}$ was carried out using a nickel column chromatography (HisTrap HP, GE Healthcare life science) on a chromatographic purification system, Acta start (GE Healthcare life science). The eluted proteins from the column were desalted and concentrated using a 10-kDacut-off centriprep (Amicon). The purity was checked with a routine sodium dodecyl sulphate- polyacrylamide gel electrophoresis (SDS PAGE). 
The $\mathrm{scFv}$ antibody and reactivity of $\mathrm{ScFv}$ against nucleoprotein and $\mathrm{H5N} 1$ virus

Rabbits were immunized with $1 \mathrm{mg}$ of the purified $\mathrm{NP}-\mathrm{scF}$ intramuscularly using Quil $\mathrm{A}$ as adjuvant. Booster immunizations were given in a 4 weeks interval. Immune response was monitored using an ELISA with purified $\mathrm{scFv}$ as the coating antigen. Two weeks after the last immunization, the rabbits were anaesthetized and bled to death. The sera were aliquoted and stored at $-20^{\circ} \mathrm{C}$.

An ELISA and dot blot were used to analyze reactivity of $\mathrm{scFv}$ against $\mathrm{NP}$ or delipidated H5N1. The plate was coated with NP (20 ng/well) or delipidated H5N1 $\left(\approx 200 \mathrm{EID}_{50} /\right.$ well). After blocking with $1 \%$ BSA, purified $\mathrm{scFv}$ was added and incubated for $2 \mathrm{hr}$. After washing 5 times with PBST, the rabbit-anti-scFv at 1: 500 dilution was added and incubated $2 \mathrm{hr}$. After washing 5 times with PBST, substrate and ABTS were added, and optical density was measured after $15 \mathrm{~min}$.

For dot-blot assay, $3 \mu \mathrm{l}$ suspension containing either $30 \mathrm{ng} \mathrm{NP}$ or $100 \mathrm{EID}_{50}$ delipidated H5N1 virus were spotted onto a nitrocellulose strip. After blocking with $1 \%$ BSA, purified $\mathrm{scFv}$ was added and incubated for 2 hr. After washing 5 times with PBST, rabbit-anti-scFv serum at 1: 500 dilution was added and incubated $2 \mathrm{hr}$. After washing 5 times with PBST, the membrane strip was developed in substrate and chromogenic 3'diaminobenzidine (DAB).

\section{RESULTS AND DISCUSSION}

The present study successfully isolated $\mathrm{scFv}$ monoclonal antibody that recognized recombinant NP from influenza $\mathrm{H} 1 \mathrm{~N} 1$ and $\mathrm{H} 5 \mathrm{~N} 1$ influenza virion. The capacity of recognizing both influenza-virus subtypes is attributed to the panning strategy used in this study, which is alternating NP and H5N1 as baits, and elution of bound phages with anti-H5N1 serum.

Delipidation of $\mathrm{H} 5 \mathrm{~N} 1$ virion, as carried out in this study, was supposed to increase its immobilization on the polystyrene surface of the immunotube and plate. Tight binding of the virion to the immunotube was necessary to withstand intensive (12 times) washings during the panning process. Previously, when NP was used as bait singly or as the only bait, the isolated $\mathrm{scFv}$ recognized the NP but not $\mathrm{H} 5 \mathrm{~N} 1$ virion. As far as we were aware, this panning approach together with the elution with the anti-serum had not been used previously.

After the first panning, the reactivity of phage to NP was still unapparent (Figure 1). The reactivity was similar to that of the control, M1307 helper phage. After the second panning, either the first with NP and the second with NP or H5N1 virus, or the first with $\mathrm{H} 5 \mathrm{~N} 1$ virus and the second with $\mathrm{NP}$, however, the reactivity increased impressively. For unknown reason, however, the reactivity of the phage after panning twice with $\mathrm{H} 5 \mathrm{~N} 1$ virus remained undetected. Reactivity of phage after the third panning on NP is presented on Table 1. The phages, which were rescued from randomly selected colonies of TG1 E. coli, had comparable reactivity. The reactivity, as expressed in ELISA OD's, were about 4 times as higher as that of M1307 helper phage control.

For the production of soluble anti-scFv antibody, the phagemid from the suppressive TG1 E. coli was isolated and expressed in a suppressive E. coli strain, HB2151. Only in this non-suppressive strain does the amber stop codon (TAG), which placed as the last codon of $\mathrm{scFv}$, function as a proper stop codon.

Considerable amount of phagemid, 7.8 and $3.8 \mu \mathrm{g}$, respectively, was isolated from two colonies of TG1-E. coli harboring phage with high reactivity to the NP. When competent HB2151 E. coli cells were transformed with the NP-scFv-phagemid, they produced a high number of colonies on carbencillin-LB-agar plates due to the presence amphicilin-resistant gene in the phagemid. Ninety colonies were randomly selected and the capacity of each colony to expressed scFv recognizing NP is presented in Table 2. One colony (\#47) expressing $\mathrm{scFv}$ with the highest reactivity was chosen for further $\mathrm{scFv}$ purification.

In $E$. coli proteins are synthesized in the cytoplasm, some of which, however, may be translocated into the periplasmic compartment, and proteins accumulated in the periplasmic compartment may, in turn, leak out into the culture medium (Kipriyanov et al. 1997). The amount of proteins leaking into the medium depend on the primary structure or amino acid sequence of the protein, stability of membrane, composition of the media and duration of incubation (Bäcklund 2008). In regard to protein purification, purification of expressed protein from the culture media is easier than that from the periplasmic or cytoplasmic spaces

In addition to the antibiotic resistance gene, the phagemid used in this study also equipped with the ompA leader sequence, which translocated the newly synthesized $\mathrm{scFv}$ from cytoplasm to the periplasmic compartment where the disulphide bonds stabilizing the molecule were formed. Also, to ease protein purification, the phagemid was equipped with a DNA sequence encoding poly histidin as a tag at the $\mathrm{C}$ terminal of the $\mathrm{scFv}$ protein. 


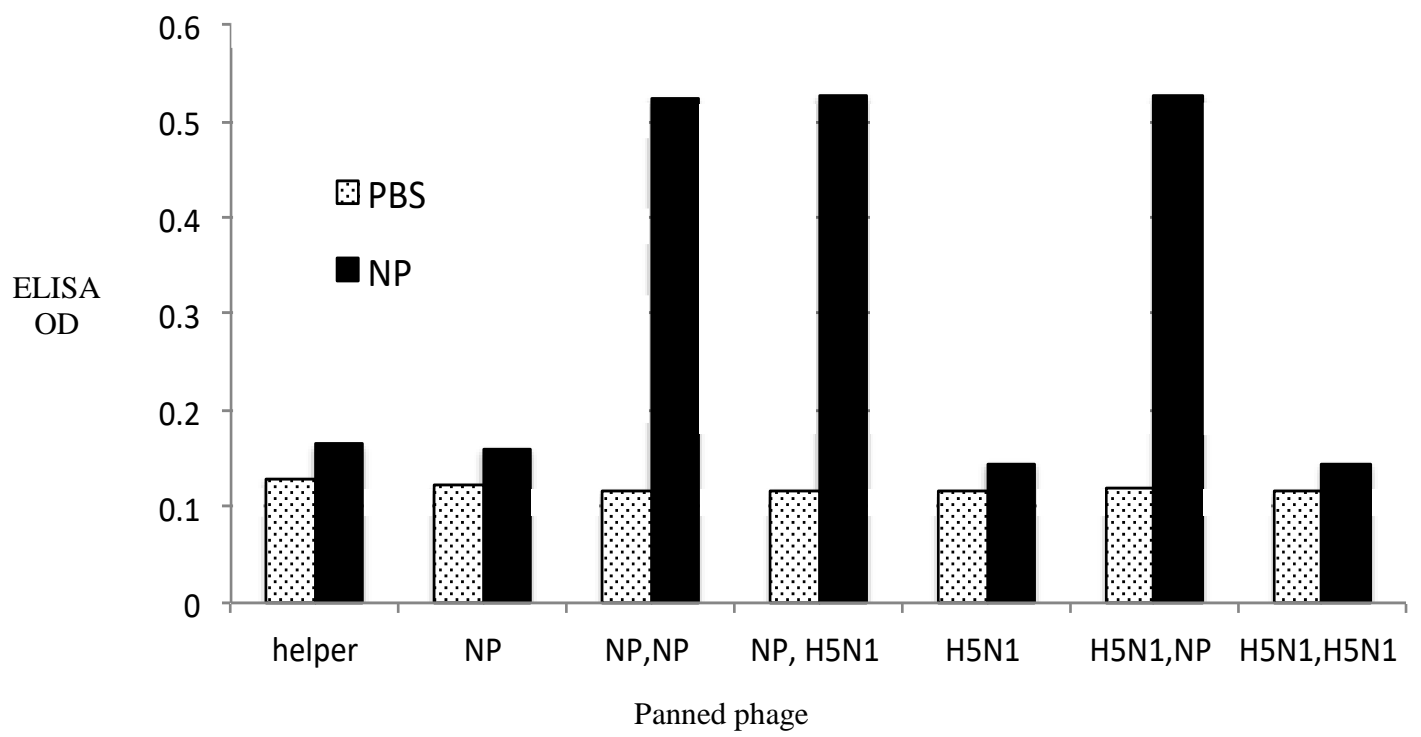

Figure 1. Reactivity of phages to NP or H5N1 after the first or second panning. The symbol NP or H5N1 on the $\mathrm{x}$-axis denotes the bait used in the panning. Two codes separated by a comma, eg. NP, H5N1, represent baits used in the first and second panning, respectively. The symbol "Helper" represents M13O7 helper phage used as a control.

Table 1. Reactivity of phage after the third panning on NP bait, propagated and rescued from randomly selected colonies of TG1 E. coli

\begin{tabular}{|c|c|c|c|c|c|c|}
\hline \multicolumn{2}{|c|}{ Phage H5N1-NP } & \multicolumn{2}{|c|}{ Phage NP-NP } & \multicolumn{2}{|c|}{ Phage NP-H5N1 } & \multirow{2}{*}{$\begin{array}{l}\text { Helper phage } \\
\text { ELISA OD }\end{array}$} \\
\hline Colony & ELISA OD & Colony & ELISA OD & Colony & ELISA OD & \\
\hline $5 \mathrm{~A}$ & 1.4165 & $6 \mathrm{~A}$ & 1.5435 & $7 \mathrm{~A}$ & 1.6195 & 0.413 \\
\hline $5 B *$ & 1.347 & $6 \mathrm{~B}$ & 0.913 & $7 \mathrm{~B}$ & 1.5595 & \\
\hline $5 C^{*}$ & 1.636 & $6 \mathrm{C}$ & 1.3795 & $7 \mathrm{C}$ & 1.337 & \\
\hline $5 \mathrm{D}$ & 1.585 & $6 \mathrm{D}$ & 1.0225 & $7 \mathrm{D}$ & 1.461 & \\
\hline $5 \mathrm{E}$ & 1.3265 & $6 \mathrm{E}$ & 1.5665 & $7 \mathrm{E}$ & 1.384 & \\
\hline $5 \mathrm{~F}$ & 1.5985 & $6 \mathrm{~F}$ & 1.512 & $7 F$ & 1.453 & \\
\hline $5 \mathrm{G}$ & 1.666 & $6 \mathrm{G}$ & 1.616 & $7 \mathrm{G}$ & 1.479 & \\
\hline $5 \mathrm{H}$ & 1.565 & $6 \mathrm{H}$ & 1.5535 & $7 \mathrm{H}$ & 1.471 & \\
\hline $5 \mathrm{I}$ & 1.6155 & $6 \mathrm{I}$ & 1.429 & $7 \mathrm{I}$ & 1.492 & \\
\hline $5 \mathrm{~J}$ & 1.326 & $6 \mathrm{~J}$ & 1.1265 & $7 \mathrm{~J}$ & 1.181 & \\
\hline $5 \mathrm{~K}$ & 1.5345 & $6 \mathrm{~K}$ & 1.4365 & & & \\
\hline $5 \mathrm{~L}$ & 1.647 & $6 \mathrm{~L}$ & 1.491 & & & \\
\hline $5 \mathrm{M}$ & 1.5515 & $6 \mathrm{M}$ & 1.439 & & & \\
\hline $5 \mathrm{~N}$ & 1.3115 & $6 \mathrm{~N}$ & 1.474 & & & \\
\hline 50 & 1.5675 & $6 \mathrm{O}$ & 1.4735 & & & \\
\hline
\end{tabular}

(*) colonies from which phagemid was isolated and used to transform competent HB2151 E. coli 
Table 2. Reactivity of supernatants from randomly selected 90 colonies of HB2151 E.coli transformed with phagemid that had undergone thrice panning with $\mathrm{NP}$ and $\mathrm{H} 5 \mathrm{~N} 1$ virus (colonies\# 5B and 5C, Table 1)

\begin{tabular}{lcccccccccccc}
\hline \hline Col \# & OD & Col \# & OD & Col \# & OD & Col \# & OD & Col \# & OD & Col \# & OD \\
\hline 1 & 0.408 & 16 & 0.394 & 31 & 0.372 & 46 & 0.363 & 61 & 0.361 & 76 & 0.384 \\
2 & 0.427 & 17 & 0.457 & 32 & 0.41 & $47 *$ & 0.604 & 62 & 0.32 & 77 & 0.364 & 0.376 \\
3 & 0.366 & 18 & 0.391 & 33 & 0.428 & 48 & 0.424 & 63 & 0.37 & 78 & 0.381 \\
4 & 0.356 & 19 & 0.361 & 34 & 0.389 & $49 *$ & 0.451 & 64 & 0.397 & 79 & & 0.484 \\
5 & 0.34 & 20 & 0.371 & 35 & 0.355 & 50 & 0.431 & 65 & 0.411 & 80 & & 0.418 \\
6 & 0.349 & 21 & 0.371 & 36 & 0.349 & 51 & 0.408 & 66 & 0.378 & 81 & & 0.43 \\
7 & 0.383 & 22 & 0.364 & 37 & 0.365 & 52 & 0.392 & 67 & 0.359 & 82 & 0.392 \\
8 & 0.398 & 23 & 0.395 & 38 & 0.376 & 53 & 0.347 & 68 & 0.37 & 83 & 0.331 \\
9 & 0.387 & 24 & 0.418 & 39 & 0.375 & 54 & 0.34 & 69 & 0.377 & 84 & 0.366 \\
10 & 0.39 & 25 & 0.396 & 40 & 0.401 & 55 & 0.374 & 70 & 0.331 & 85 & 0.358 \\
11 & 0.354 & 26 & 0.368 & 41 & 0.428 & 56 & 0.412 & 71 & 0.369 & 86 & 0.372 \\
12 & 0.36 & 27 & 0.351 & 42 & 0.38 & 57 & 0.396 & 72 & 0.363 & 87 & 0.364 \\
13 & 0.374 & 28 & 0.307 & 43 & 0.36 & 58 & 0.355 & 73 & 0.391 & 88 & 0.37 & \\
14 & 0.386 & 29 & 0.353 & 44 & 0.381 & 59 & 0.356 & 74 & 0.395 & 89 & 0.43 \\
15 & 0.38 & 30 & 0.359 & 45 & 0.372 & 60 & 0.327 & 75 & 0.375 & 90 & 0.42 \\
\hline
\end{tabular}

Expression of anti-NP scFv antibody in the present study revealed that the amount of $\mathrm{scFv}$ recovered from culture supernatant was larger than that from periplasmic compartment. Based on SDS PAGE, the major protein eluted from the nickel-ion-affinity chromatography had a molecular weight of about 27 $\mathrm{kDa}$, similar to that of expected scFv (Figure 2). This protein was highly immunogenic, as a high titre against the NP-scFv was obtained after the fifth immunization of rabbits. At 1: 1600 dilutions, the antiserum recognized the $\mathrm{scFv}$ coated on micro titre plate at a concentration of $44 \mathrm{ng} / \mathrm{ml}$. At lower dilutions (1:200), it recognized at a concentration of $5 \mathrm{ng} / \mathrm{ml}$.

The purified $\mathrm{scFv}$ proved to recognized NP and H5N1 both in dot blot and ELISA (Figure 3 and 4). In dot blot experiment, the bindings of $\mathrm{scFv}$ to $\mathrm{NP}$ and to $\mathrm{H} 5 \mathrm{~N} 1$ virion were probed by the rabbit anti scFv serum. This experiment also proved the specificity of the antibody, as no signal was observed when the binding was probed with normal or pre-vaccinated serum (Figure 3). Results of this dot blot experiment were in agreement with those of ELISA. The rabbit anti-scFv serum affirmed the binding of purified $\mathrm{scFv}$ to NP or to $\mathrm{H} 5 \mathrm{~N} 1$ virion. The binding $\mathrm{scFv}$ to $\mathrm{NP}$ or $\mathrm{scFv}$ to $\mathrm{H} 5 \mathrm{~N} 1$ that was probed with the rabbit anti-scFv serum prompted ELISA ODs that were about five times higher than those probed with negative serum. The binding $\mathrm{scFv}$ to $\mathrm{NP}$ or $\mathrm{scFv}$ to $\mathrm{H} 5 \mathrm{~N} 1$ that was probed with the rabbit anti-scFv serum produced ELISA ODs that were about five times higher than that probed with negative serum. Non-specific bindings between the negative serum with $\mathrm{scFv}, \mathrm{NP}$ or $\mathrm{H} 5 \mathrm{~N} 1$ were negligible. For unknown reason, however, there was some non-specific binding between the anti-scFv serum with NP or H5N1 (Figure 4).

Comparable approach to the present study had been used by previous studies in an attempt to isolate $\mathrm{scFv}$ recognizing parvalbumin allergen from various species of fish (Bublin et al. 2015). For that purpose, the group carried out three sequential panning on cod, carp and rainbow-trout parvalbumins, respectively.

One of the most common problems in $\mathrm{scFv}$ production is the low yield of functional $\mathrm{scFv}$ that can be purified from the prokaryotic expression system. The causes of the problem include inhibition of culture growth by toxic effect of the expressed $\mathrm{scFv}$, formation of insoluble aggregates in the periplasmic compartment, and plasmid instability (Mergulhao et al. 2005; Rippmann et al. 1998). To be functional, a scFv required a post-translational processing, that is the formation of disulphide bridges (Montoliu-Gaya et al. 2017; Ramm et al. 1999). Formation of disulphide bonds in prokaryotic cells is taken place only in the periplasmic compartment because only in this compartment the oxidative environment and required enzymes are available (Eser et al. 2009; Makrides 1996). 


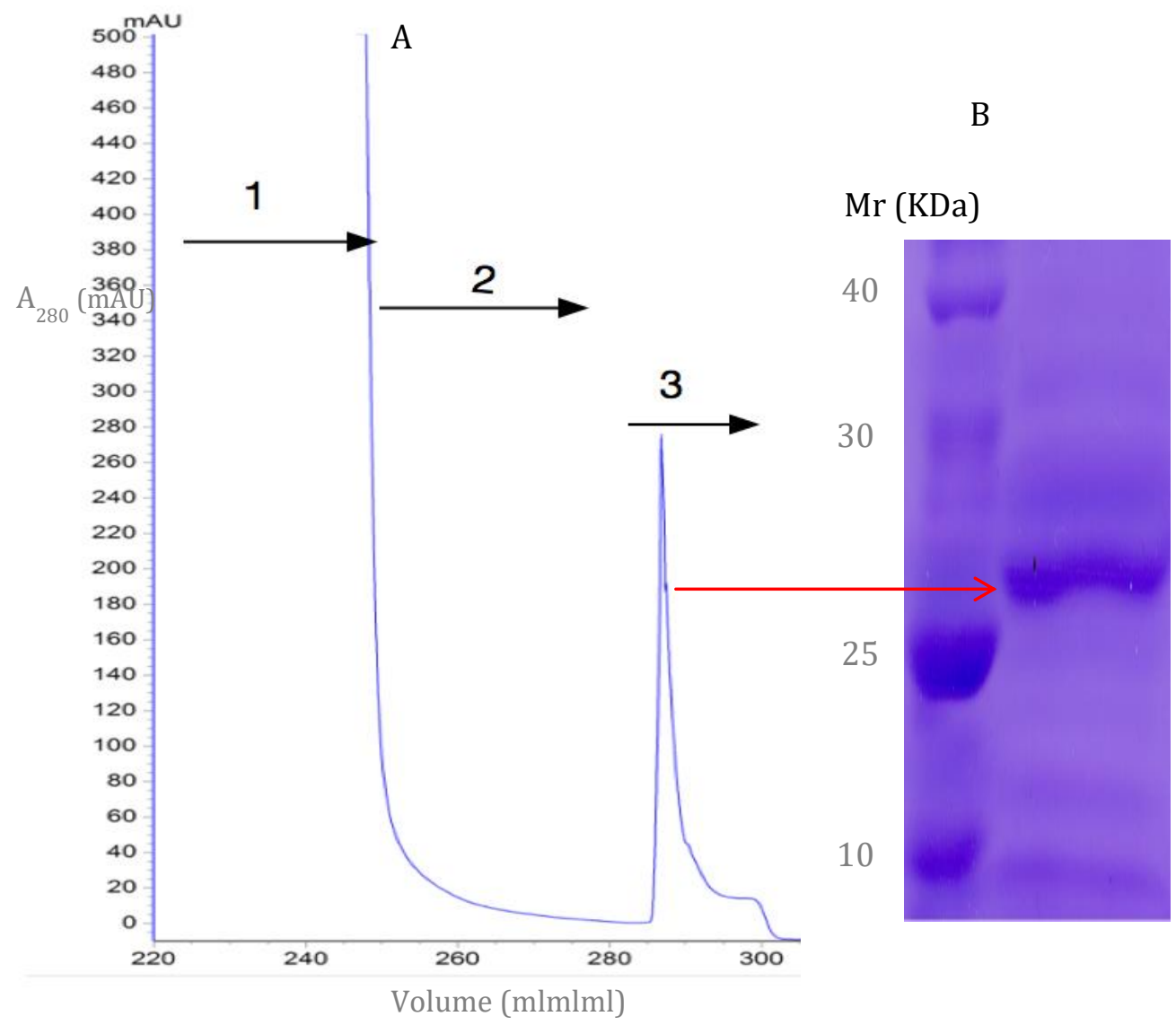

Figure 2. A: Purification scFv from culture supernatant of HB2151 E. coli transformed with anti-NP phagemid. Culture supernatant was loading into a 5-ml-affinity column (HisTrap $\left.\mathrm{HP}^{\circledR}\right)(1)$, unbound proteins were washed off from the column (2), bound protein (scFv) was eluted with imidazole solution (3).

B: Coomasie-blue stained SDS PAGE of protein eluted from affinity column after desalting and concentration. The elution contains a single protein with $\mathrm{a} \approx 27 \mathrm{kDa}$ size, similar to that of $\mathrm{scFv}$ (red arrow).

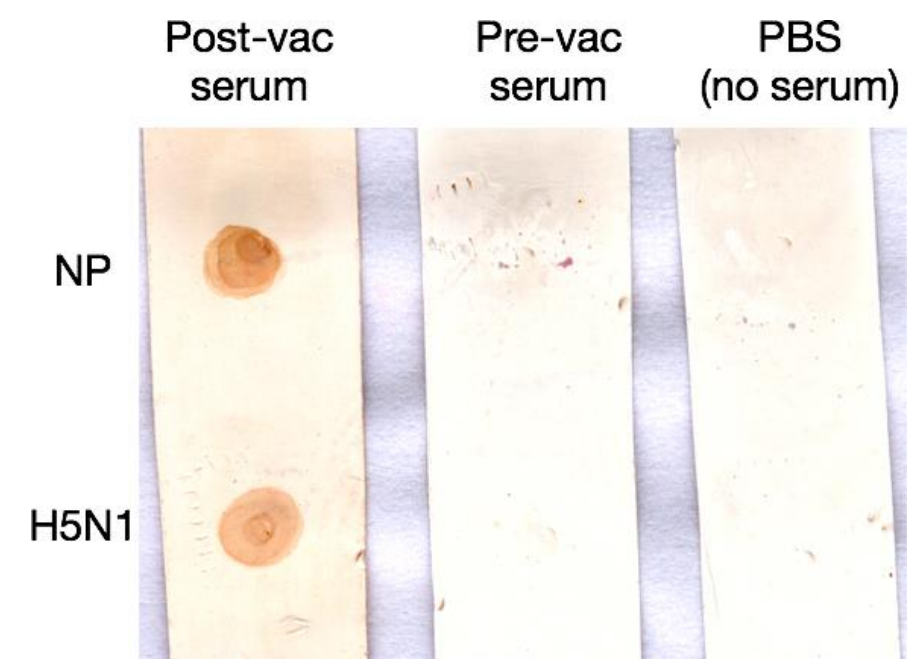

Figure 3. Reactivity of scFv against H1N1 nucleoprotein (NP) and H5N1 virion by dot blot. The NP (1 $\mu$ g) or delipidated H5N1 $\left(\approx 100 \mathrm{EID}_{50}\right)$ is spotted onto nitrocellulose strips, the $\mathrm{NP}-\mathrm{scFv}$ was added and probed with rabbit anti-scFv serum (post-vac serum), normal rabbit serum (pre-vac serum) or PBS (control). 
A

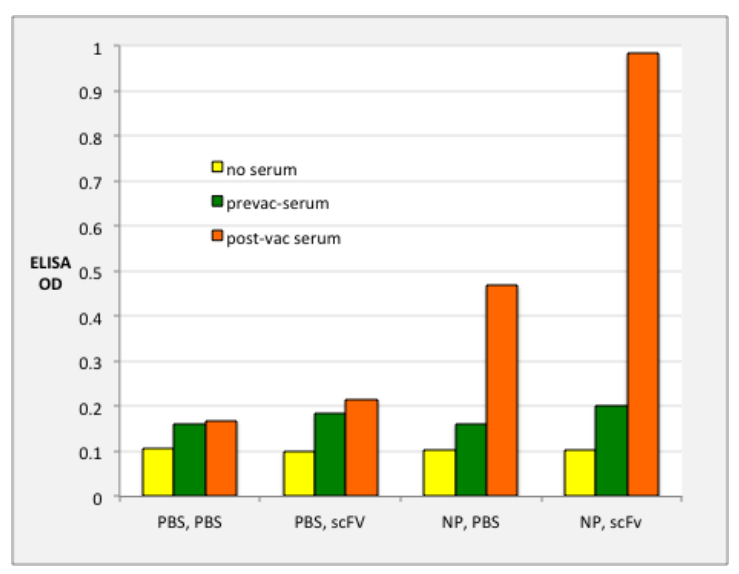

B

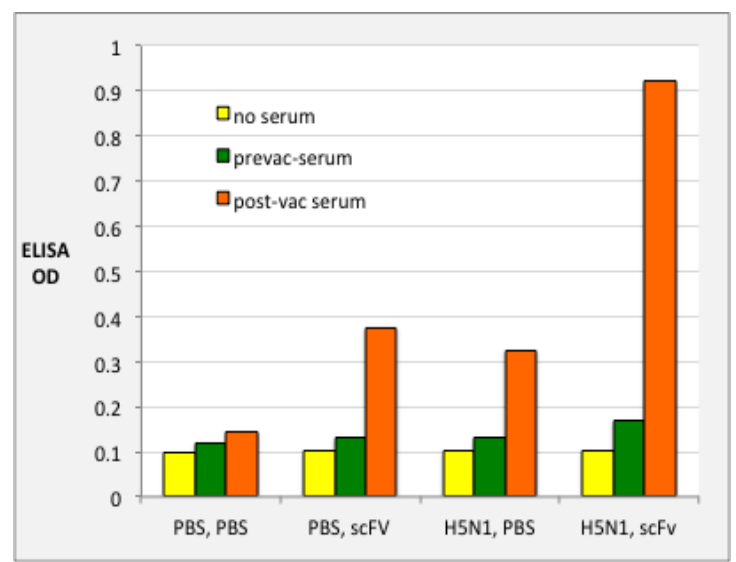

Figure 4. Reactivity of $\mathrm{scFv}$ against H1N1 nucleoprotein (NP) (A) and against H5N1 virion (B) by ELISA. Micro-titer plate wells coated with NP, H5N1 or PBS (control) were added either scFv or PBS (control). After washings, rabbit anti-NP-scFv serum (post-vac serum), normal rabbit serum (pre-vac serum) or PBS (control) were added.

Although the functional $\mathrm{scFv}$ accumulated in the periplasmic space, some of them may leak out into the culture medium (Kipriyanov et al. 1997). In this study, the amount of $\mathrm{scFv}$ purified from the culture medium was found to be higher than that from the periplasmic compartment isolated by the cold osmotic shock method (Neu \& Heppel 1965). For this reason, isolation of $\mathrm{scFv}$ was only carried out from this compartment. In addition, isolation of proteins from the culture medium is easier that that from periplasmic compartment (Kipriyanov et al. 1997).

In the present study, about $1.2 \mathrm{mg}$ of anti-NP-scFv antibody per litre culture was obtained. This yield is considered to be high as compared to previous studies; $0.59 \mathrm{mg} / \mathrm{L}$ (Mesgari-Shadi \& Sarrafzadeh 2017) or 0.1 $\mathrm{mg} / \mathrm{L}$ (Kipriyanov et al. 1997). Eukaryotic cells are apparently more efficient than prokaryotic cells in expressing functional $\mathrm{scFv}$. An expression of $\mathrm{scFv}$ in mammalian HEK293T cells was reported to obtain a yield of 12.87 to $33.56 \mathrm{mg} / \mathrm{L}$ culture (Pipattanaboon et al. 2017). Yeast (Pichia pastoris) expression system was reported to obtain even higher yield, $100 \mathrm{mg} / \mathrm{L}$ of pure and functional rabbit anti-rhLIF $\mathrm{scFv}$ antibody (Ridder et al. 1995).

Various attempts to increase $\mathrm{scFv}$ yields in prokaryotic expression system have been made. Kipriyanov and group reported that addition of sucrose to the medium resulted in the yield of $16.5 \mathrm{mg} / \mathrm{L} \mathrm{scFv}$ or $80-150$ fold higher than that without sucrose addition (Kipriyanov et al. 1997). Similar results were also obtained by others (Mesgari-Shadi \& Sarrafzadeh 2017; Sawyer et al. 1994). In our study, however, no increase in the yield was observed when sucrose was added to the culture media. This means that addition of sucrose to the culture does not always increase the functional $\mathrm{scFv}$ yield. As a matter of fact, Sina and group reported that addition of sucrose to the culture media even suppressed the expression of $\mathrm{scFv}$ (Sina et al. 2015). The cause of the differences in the response to the sucrose is unknown but it might be related to the primary sequence of the scFv (Takkinen et al. 1991). In addition to the primary sequence of the $\mathrm{scFv}$, there are some other factors may affect the expression of $\mathrm{scFv}$ in prokaryotic cells including duration, temperature, aeration and gene induction. Each of those factors needs to be optimalisized for every $\mathrm{scFv}$, which is time consuming when carried out in flask cultures. However, a simple optimaliation can be carried out in using a fermentor by sequential simplex optimization method (Intachai et al. 2015).

\section{CONCLUSION}

A scFv-monoclonal antibody recognizing nucleoprotein of influenza virus was isolated by panning a commercial-influenza-A- focused- $\mathrm{scFv}$ library. Panning with the alternating H1N1 NP and $\mathrm{H} 5 \mathrm{~N} 1$ virion, and elution with $\mathrm{H} 5 \mathrm{~N} 1$ antiserum assure the isolated $\mathrm{mAb}$ recognizes multiple, if not all, subtype of influenza-A viruses. The anti NP-scFv antibody was purified to homogeneity using an affinity chromatography. Rabbits immunized with this purified $\mathrm{NP}-\mathrm{scF}$ produced specific antibody that recognized $\mathrm{NP}-\mathrm{scFv}$ even in a very low concentration in immunoassays. The immunoassays carried out in this study suggest that the NP-scFv mAb and the rabbit anti $\mathrm{NP}-\mathrm{scFv}$ can be use in developing point-of-care diagnostic tools for Avian Influenza. 


\section{REFERENCES}

Bäcklund E. 2008. Growth rate control of periplasmic product retention in Escherichia coli (Thesis). [Stockholm (UK)]: Royal Institute of Technology.

Bublin M, Kostadinova M, Fuchs JE, Ackerbauer D, Moraes AH, Almeida FC, Lengger N, Hafner C, Ebner C, Radauer C, Liedl KR, Valente AP, Breiteneder H. 2015. A cross-reactive human single-chain antibody for detection of Major Fish Allergens, Parvalbumins, and identification of a Major IgE-Binding epitope. PLoS One. 10:e0142625.

Cham BE, Knowles BR. 1976. A solvent system for delipidation of plasma or serum without protein precipitation. J Lipid Res. 17:176-181.

Chung CT, Niemela SL, Miller RH. 1989. One-step preparation of competent Escherichia coli: Transformation and storage of bacterial cells in the same solution. Proc Natl Acad Sci. 86:2172-2175.

Clackson T, Hoogenboom HR, Griffiths AD, Winter G. 1991. Making antibody fragments using phage display libraries. Nature. 352:624-628.

Eser M, Masip L, Kadokura H, Georgiou G, Beckwith J. 2009. Disulfide bond formation by exported glutaredoxin indicates glutathione's presence in the $\mathrm{E}$. coli periplasm. Proc Natl Acad Sci. 106:1572-1577.

[FAO] Food Agriculture Association. 2013. Lessons from HPAI-A technical stocktaking of coutputs, outcomes, best practices and lessons learned from the fight against highly pathogenic avian influenza in Asia 2005-2011. Rome (Italy): Food Agriculture Association.

Hoogenboom HR, de Bruine AP, Hufton SE, Hoet RM, Arends JW, Roovers RC. 1998. Antibody phage display technology and its applications. Immunotechnology. $4: 1-20$.

Intachai K, Singboottra P, Leksawasdi N, Kasinrerk W, Tayapiwatana C, Butr-Indr B. 2015. Enhanced production of functional extracellular single chain variable fragment against HIV-1 matrix protein from Escherichia coli by sequential simplex optimization. Prep Biochem Biotechnol. 45:56-68.

Kipriyanov SM, Moldenhauer G, Little M. 1997. High level production of soluble single chain antibodies in smallscale Escherichia coli cultures. J Immunol Methods. 200:69-77.

Kohler G, Milstein C. 1975. Continuous cultures of fused cells secreting antibody of predefined specificity. Nature. 256:495-497.

Liu JK. 2014. The history of monoclonal antibody development - Progress, remaining challenges and future innovations. Ann Med Surg. 3:113-116.

Makrides SC. 1996. Strategies for achieving high-level expression of genes in Escherichia coli. Microbiol Rev. 60:512-538.
Mergulhao FJ, Summers DK, Monteiro GA. 2005. Recombinant protein secretion in Escherichia coli. Biotechnol Adv. 23:177-202.

Mesgari-Shadi A, Sarrafzadeh MH. 2017. Osmotic conditions could promote $\mathrm{scFv}$ antibody production in the Escherichia coli HB2151. Bioimpacts. 7:199-206.

Montoliu-Gaya L, Martinez JC, Villegas S. 2017. Understanding the contribution of disulfide bridges to the folding and misfolding of an anti-Abeta scFv. Protein Sci. 26:1138-1149.

Neu HC, Heppel LA. 1965. The Release of Enzymes from Escherichia coli by Osmotic Shock and during the Formation of Spheroplasts. J Biol Chem. 240:36853692 .

Nissim A, Hoogenboom HR, Tomlinson IM, Flynn G, Midgley C, Lane D, Winter G. 1994. Antibody fragments from a 'single pot' phage display library as immunochemical reagents. EMBO J. 13:692-698.

Pipattanaboon C, Boonha K, Benjathummarak S, Pitaksajjakul P, Ramasoota P. 2017. Construction and expression of H5N1 influenza virus hemagglutininspecific scFv-Fc monoclonal antibodies in HEK293T cells. Southeast Asian J Trop Med Public Health. 48:4555 .

Ramm K, Gehrig P, Pluckthun A. 1999. Removal of the conserved disulfide bridges from the $\mathrm{scFv}$ fragment of an antibody: effects on folding kinetics and aggregation. J Mol Biol. 290:535-546.

Ridder R, Schmitz R, Legay F, Gram H. 1995. Generation of rabbit monoclonal antibody fragments from a combinatorial phage display library and their production in the yeast Pichia pastoris. Biotechnology. 13:255-260.

Rippmann JF, Klein M, Hoischen C, Brocks B, Rettig WJ, Gumpert J, Pfizenmaier K, Mattes R, Moosmayer D. 1998. Procaryotic expression of single-chain variablefragment $(\mathrm{scFv})$ antibodies: secretion in L-form cells of Proteus mirabilis leads to active product and overcomes the limitations of periplasmic expression in Escherichia coli. Appl Environ Microbiol. 64:4862-4869.

Sawyer JR, Schlom J, Kashmiri SV. 1994. The effects of induction conditions on production of a soluble antitumor $\mathrm{sFv}$ in Escherichia coli. Protein Eng. 7:14011406.

Shalit I, McKee PA, Beauchamp H, Waner JL. 1985. Comparison of polyclonal antiserum versus monoclonal antibodies for the rapid diagnosis of influenza A virus infections by immunofluorescence in clinical specimens. J Clin Microbiol. 22:877-879.

Sina M, Farajzadeh D, Dastmalchi S. 2015. Effects of Environmental Factors on Soluble Expression of a Humanized Anti-TNF-alpha $\mathrm{scFv}$ Antibody in Escherichia coli. Adv Pharm Bull. 5:455-461.

Smith GP, Petrenko VA. 1997. Phage display. Chem Rev. 97:391-410 
Takkinen K, Laukkanen ML, Sizmann D, Alfthan K, Immonen T, Vanne L, Kaartinen M, Knowles JK, Teeri TT. 1991. An active single-chain antibody containing a cellulase linker domain is secreted by Escherichia coli. Protein Eng. 4:837-841.

Tarigan S. 2016. Peranan point-of-care test dalam pengendalian highly pathogenic Avian Influenza di Indonesia. Wartazoa. 26:39-50.

Tarigan S, Indriani R, Durr PA, Ignjatovic J. 2015. Characterization of the M2e antibody response following highly pathogenic $\mathrm{H} 5 \mathrm{~N} 1$ avian influenza virus infection and reliability of M2e ELISA for identifying infected among vaccinated chickens. Avian Pathol. 44:259-268

Thompson J, Pope T, Tung JS, Chan C, Hollis G, Mark G, Johnson KS. 1996. Affinity maturation of a highaffinity human monoclonal antibody against the third hypervariable loop of human immunodeficiency virus: use of phage display to improve affinity and broaden strain reactivity. J Mol Biol. 256:77-88. 